\title{
Experience of our surgery in iatrogenic vesicovaginal fistulas
}

\author{
Iatrojenik vezikovajinal fistüllerde cerrahi deneyimlerimiz
}

\author{
Ateş Karateke², Mehmet Reşit Asoğlu'ㄹ, Selçuk Selçuk ${ }^{1}$, Çetin Çam ${ }^{1}$, Niyazi Tuğ ${ }^{1}$, Armağan Özdemir ${ }^{2}$ \\ ${ }^{1}$ Department of Obstetrics and Gynecology, Faculty of Medicine of University of Yeditepe, Istanbul, Turkey \\ ${ }^{2}$ Department of Obstetrics and Gynecology, Zeynep Kamil Teaching Researching Hospital, Istanbul, Turkey
}

\section{Abstract}

O bjective: In this study, transvesical and transvaginal approaches used in our clinic for the treatment of gynecologic iatrogenic vesicovaginal fistulas are discussed.

M aterial and M ethods: 11 patients with vesicovaginal fistula admitted to the Department of Urogynecology, Zeynep Kamil TeachingResearch Hospital between 2005-2009 were enrolled in our study. Transvesical and transvaginal fistula repair were performed on all patients. All patients were treated by surgical repair, 4 cases by a classic transabdominal approach, 5 cases by an omental flap interposition and 2 cases by a martius flap interposition.

Results: The most common cause of iatrogenic vesicovaginal fistula in our patients was total abdominal hysterectomy for benign conditions $(n=10 / 11)$. The mean patient age was 43 years (34-53) and the mean time from the causative surgery to the operation was 7.5 months (3-12). The surgical techniques were successful in all patients. There were no intraoperative complications and no postoperative recurrences.

Conclusion: The mouth of the fistula should be determined clearly on preoperative evaluation and surgery procedure should be planned according to the fistula aperture. The point to be careful of is excision of all diseased tissue in the bladder and vagina, complete separation of the bladder from the vagina with a margin of healthy tissue, and watertight closure of both bladder and vagina without tension. The aim of the vascularized tissue interposition between the closed bladder and the vagina is to provide the improvement of vascularity. We believe that in the treatment of supratrigonal and large fistulas, the transvesical approach with use of omental flap interposition is more effective, while, in the treatment of small and trigonal fistula,the transvaginal approach with use of martius flap interposition is an effective tecnique. (J Turkish-German Gynecol Assoc 2010; 11: 137-40)

Key words: latrogenic vesicovaginal fistula, martius flap, omental flap

Received: 28 April, 2010

Accepted: 1July, 2010

\section{Introduction}

Urogenital fistulae are among the most dreaded complications encountered in obstetrics and gynecology and constitute a major surgical challenge for the urogynecologist. A vesicovaginal fistula is rare but its impact lies in the social distress that results from persistent leakage of urine. The overall incidence varies between 0.5 and $1.5 \%$, and bladder

\section{Özet}

Amaç: Bu çalışmada kliniğimizde jinekolojik iatrojenik vezikovajinal fistül nedeniyle uyguladığımız transvezikal ve transvajinal tedavi yaklaşımımız tartşsılmıştır.

Gereç ve Yöntemler: 2005-2009 yıllan arasında Zeynep Kamil Eğitim Araşturma Hastanesi Ürojinekoloji Kliniğine başvuran 11 kadın hastaya vezikovajinal fistül tanısıyla transvajinal ve transvezikal fistül onanmı uyguladık. Bu hastalara yaklaşımda 4 hastaya klasik abdominal yaklaşım, 5 hastaya omentum interpozisyonu, 2 hastaya martius flep interpozisyonu yapıldı.

Bulgular: Hastalanmızda vezikovajinal fistülün en sık sebebi benign nedenlerle yapılan total abdominal histerektomi bulundu $(n=10 / 11)$. Hastalann ortalama yaşı 43 yıl (34-53), ortalama semptomatik dönemi 7.5 ay (3-12) olarak hesapland. Cerrahi teknikler tüm hastalarda başanlı oldu. Hastalann hiçbirinde intraoperatif komplikasyon ve postoperatif dönemde nüks olmadı.

Sonuç: Vezikovajinal fistül hastalannda preoperatif değerlendirmede fistülün vajinal ve mesane ağızlan net olarak tespit edilmelidir ve yapılacak cerrahi yaklaşıma buna göre karar verilmedir. Dikkat edilmesi gereken nokta mesane ve vajinadan hastalıklı dokulann çıkartılıp, tamamen ayn ayn tabakalı, sızınt olmayacak şekilde, sağlam doku sınınndan ve gerilim olmadan onanımasıdır. Onanlan mesane ve vajina arasına vaskülerize doku interpozisyonu kanlanmayı artrmak için uygulanır. Fistülün küçük, trigonal yerleşimli olduğu olgularda martius flep interpozisyonunun kullanıldığı transvajinal yol etkili bir yöntem olmakla birlikte; fistülün büyük, supratrigonal yerleşimli olduğu olgularda abdominal yaklaşımın daha etkili olduğuna inanıyoruz.

(J Turkish-German Gynecol Assoc 2010; 11: 137-40)

Anahtar kelimeler: İatrojenik vezikovajinal fistül, martius flep, omental flep

Geliş Tarihi: 28 Nisan 2010

Kabul Tarihi: 01 Temmuz 2010

injuries are more common than ureteric ones $(1,2)$. The WF is the most common and the vesicouterine fistula the least common variety among the genitourinary fistulae $(3,4)$. Early in the past century, the most common cause of the VVF was complicated childbirth with tissue injury. With modern obstetric services, these fistulas are rare, and the most common cause, $75-90 \%$ of all WF, is total abdominal hysterectomy $(5,6)$. In addition, some rare etiologies have been men- 
tioned in the literature, such as pelvic trauma, radiation necrosis, illegal abortion, as well as radical pelvic surgery $(7,8)$. In recent years, the rise of laparoscopic approaches has brought about an increased rate of iatrogenic injury (9). In underdeveloped countries, the most common cause of WF is still obstetric causes including complications of neglected, prolonged, or obstructed childbirth (10).

In the present study, we aimed to discuss the etiologies of 11 cases with gynecologic iatrogenic VVF which were evaluated and operated on in our clinic and the results of our experiences about applied surgery techniques in these cases.

\section{Material and Methods}

The 11 cases of vesicovaginal fistulae, which were operated on in our department of urogynecology from 2005 to 2009, were included in this study. The complaints of the patients were urinary leakage from the vagina or continuous urinary incontinence. Preoperative assessment of the patients included detailed history taking, physical examination, rectovaginal examination, appropriate laboratory investigations, pelvic-abdominal ultrasound if needed, and also intravenous urography. Vaginoscopy, cystoscopy, and retrograde catheterization were applied to determine the size, site, and extent of the fistula as well as to exclude or confirm the involvement of the ureter or neck of bladder. The methylene blue dye test was carried out with the help of a tampon inserted into vagina when the fistula was not obviously seen on cystoscopy. Before cystoscopy, an intravenous pyelograph (IVP) was carried out in order to observe the upper urinary tract. After observation of the localization of fistula in the bladder and vagina, the patients were prepared for operation. Local estrogen preparations for patients showing vaginal postmenopausal atrophy and antibiotherapy for patients having infection on the fistula tract were given. Mechanical bowel preparation, when necessary, was started $48 \mathrm{~h}$ before surgery. Ceftriaxone $1 \mathrm{~g}$ and metronidazole $500 \mathrm{mg}$ were administered intravenously with induction of anesthesia. Before surgery, while patients were in the supine lithotomy position, vaginal and suprapubic areas were sterilized with a solution containing povidone-iodine. Transvaginal or transabdominal approaches were preferred as an operation technique. In the transvesical approach, layered closure with or without omental flap interposition (O'Conor technique) was used (11-13). Abdominal incision was made vertically, the bladder was mobilized widely from the underlying vagina and uterus to the level of the fistula while avoiding from ureter orifice, and the fistula tract was excised circumscribely from the living tissue margin. Closure of the bladder mucosa and muscle layers was carried out by separate suturing with interrupted 3-0 polyglactin sutures without tension in a nonoverlapping manner to achieve a watertight closure. The vaginal mucosa was then sutured separately with interrupted 3-0 polyglactin sutures. Separate closure of the bladder and vagina was achieved. The repair was reinforced with free omental flap between the bladder and vagina for the cases in which the O'Conor technique were performed. The abdomen was closed after fistula repair and the operation was completed. In the transvaginal approach, a martius flap interposition was made to reinforce repair after the fistulous tract was excised $(11,14)$. The fistula tract was excised following wide mobilization of the vagina for about 2 $\mathrm{cm}$ from the edge of the fistula. Bladder mucosa and muscular layers were repaired separately and rotated to the inner edge of the fistula with interrupted 3-0 polyglactin sutures. A vertical incision was made on the right labium major and a martius labial fat pad (Bulbocavernosus fat tissue) interposition was made from under the vaginal mucosa and labium minor and was sutured on the bladder fascia. Mobilized vaginal mucosa was repaired vertically with 2-0 polyglactin sutures without tension in a manner that covered the fat flap. The vertical incision on the labium majus was repaired separately with 3-0 silk sutures. The operation was completed with insertion of a tampon into the vagina.

\section{Results}

The mean age of patients was 43 years (range 34-53). In ten patients, the etiology of the fistula was hysterectomy performed for benign conditions, while in one patient it was a history of repeated cesarean section (Table 1 ). While in ten patients WF was primary, only one patient had secondary WF. The mean symptomatic period beginning from their operation date until referral to our hospital was 7.5 months (range 3-12). Fistula size varied between $5 \mathrm{~mm}$ and $20 \mathrm{~mm}$ (average 15) and the diameter of fistular orifices varied between $2 \mathrm{~mm}$ and $15 \mathrm{~mm}$ (average 5) (Table 2). The locations of fistulas were supratrigonal in eight patients and trigonal in three patients. Nine patients were repaired transabdominally and two patients were repaired transvaginally. Two patients with small fistula $(\leq 5 \mathrm{~mm})$ and trigonal were repaired vaginally and a martius flap interposition was applied. One patient with fistula, which was $10 \mathrm{~mm}$ and trigonal, was repaired abdominally by the O'Connor technique with an omental flap interposition. A double J catheter was placed near the mouth of the fistula in trigonal fistulas. Four patients with a fistula size greater than $10 \mathrm{~mm}$ and supratrigonal

\section{Table 1. The causes of vesicovaginal fistula}

\begin{tabular}{|l|c|}
\hline Etiology & $\mathbf{n}$ \\
\hline Hysterectomy for benign conditions* & 10 \\
\hline Repeated cesarean & 1 \\
\hline *Total abdominal hysterectomy was performed for these patients \\
\hline
\end{tabular}

Table 2. The mean age, parity, symptomatic period, diameter of fistulas, size of the fistulas

\begin{tabular}{|l|c|}
\hline Mean age (years) & $43(34-53)$ \\
\hline Mean parity & $2.3(2-4)$ \\
\hline Mean symptomatic period (month) & $7.5(3-12)$ \\
\hline Mean diameter of fistulas (mm) & $5(2-15)$ \\
\hline Mean size of the fistulas (mm) & $15(5-20)$ \\
\hline
\end{tabular}


were repaired abdominally and an omental flap interposition was made. The other four patients with a fistula size less than $10 \mathrm{~mm}$ and supratrigonal were repaired abdominally and a layered closure was made without omental flap interposition (Table 3). The average operative time was 35 min (25-45) for layered closure, $75 \mathrm{~min}$. (50-80) for omental flap (O'Conor technique) and $120 \mathrm{~min}$ (110-130) for martius flap. There were no intraoperative complications. Urinary tract infection was seen in only one patient and the other patients had no postoperative complications. Blood transfusion was not required in any of the patients. The bladder was drained by foley catheter for three weeks in trigonal fistulas and one week in supratrigonal fistulas after operation and the catheter was extracted after patients could successfully urinate. Prophylactic antibiotic was continued parenterally for the first $48 \mathrm{~h}$ postoperatively and orally until the catheter was removed. All patients were examined postoperatively after an average of 4 month (range 2-6) and recurrence of fistula was not observed.

\section{D iscussion}

The WF is the most common among the genitourinary fistulae and in developed countries, $90 \%$ of vesicovaginal fistulae are caused by gynecological procedures $(3,15)$. Hysterectomy, both by transabdominal and transvaginal approaches, is the most common procedure, comprising $75 \%$ of fistulae (16). The overall incidence varies between 0.5 and $1.5 \%$, and bladder injuries are more common than ureteric ones $(1,2)$. In pelvic surgery the development risk of WF is $0.22 \%$ in laparoscopic hysterectomy, $0.1 \%$ in abdominal hysterectomy and $0.02 \%$ in vaginal hysterectomy (9). They emerge as a complication of gynecological surgery in developed countries, or obstetric trauma in third world countries. Obstetric fistulas are usually larger than post-hysterectomy fistulas and located more distally $(5,17)$. The main symptom of WF is leakage of urine from the vagina, apparent only when the bladder is full, or constantly in the presence of a large fistula. After gynecological surgery, leakage usually appears after removal of the urinary catheter (18). Cystoscopy with vaginal examination is the most important clinical examination in the evaluation of VVF. The instillation of methylene-blue solution into the bladder is helpful in the diagnosis of small fistulas. Intravenous urography with cystography in the lateral position is necessary to discover the position of the fistulous channel and to exclude ureterovaginal fistula. WF can be treated with surgery or conservatively and the timing of repair remains controversial. According to the literature, it is apparent that there is

Table 3. The locations and diameter of fistulas and surgical techniques

\begin{tabular}{|l|l|c|c|}
\hline Diameter & $\mathbf{n}$ & Location & Surgical techniques \\
\hline$\leq 5 \mathrm{~mm}$ & 2 & Trigonal & Martius flap interposition \\
\hline $10 \mathrm{~mm}$ & 1 & Trigonal & Omental flap interposition \\
\hline$\geq 10 \mathrm{~mm}$ & 4 & Supratrigonal & Omental flap interposition \\
\hline$<10 \mathrm{~mm}$ & 4 & Supratrigonal & Only layered closure \\
\hline
\end{tabular}

no consensus as to the definition of late (2-4 months) and early (1-3 months) repair $(19,20)$. Conservative approaches such as catheter drainage, occlusion with fibrin, peeling of the tract epithelium with metal screw and steroid use have been reported in the literature for closure of small fistulas (21). We preferred late repair in all operated patients, since we believe that we relatively decreased the number of postoperative surgery failures caused by necrosis and/or inflammation of the fistula edge, through saving time for creating a fibrous tissue. In our surgeries, the preferred approaches were transvaginal and transabdominal. Important technical details include excision of all diseased tissue in the bladder and vagina, complete separation of the bladder from the vagina with a margin of healthy tissue, and watertight closure of both bladder and vagina without tension. Interposition of vascularized tissue (peritoneum, omentum, labial fat pad, gracilis muscle, myocutaneous muscle flaps) between the closed bladder and the vagina is recommended to improve vascularity $(22,23)$. Fistulas greater than $3 \mathrm{~cm}$, associated with radiotherapy or malignancy,and which involve the trigone, bladder neck and urethra are complicated fistulas and interposition of vascularized tissue can be used successfully in these cases (24-26). The first operation applied to patients with VF is the most important operation which determines the rate of success in treatment. We consider that interposition of vascularized tissue is a reasonable approach for patients eligible at the first attempt. The applied surgical approaches are dependent on many factors, together with the experience and training of the surgeon (11). In the literature, the overall success rate for simple fistulae repaired by the transabdominal layered closure technique is $87.5 \%$ and by the transvaginal route $87.09 \%(27-29)$. We have achieved success in all 11 patients $(n=11 / 11)$ on whom we operated.

In conclusion, WF is an iatrogenic and treatable condition which is hygienically, socially and psychologically devastating. We consider that, in the treatment of supratrigonal and large fistulas, the transabdominal approach using omental flap interposition is more effective,while in the treatment of small and trigonal fistula, the transvaginal approach using martius flap interposition is an effective technique. In our cases, both transvaginal and transabdominal approaches have been used considering the size and location of the fistula, and no recurrence has been observed.

As in many other developed countries, vesicovaginal fistula is also seen after simple type 1 hysterectomy in our country. Most of these fistulas are supratrigonal. Operations should not be performed unless the intravesical and intravaginal location and tracing of fistulas are known.

\section{Conflict of interest}

No conflict of interest is declared by authors.

\section{R eferences}

1. American College of Obstetricians and Gynecologists (ACOG) educational bulletin. Lower urinary tract operative injuries. Number 238, July 1997. Int J Gynaecol Obstet. 1997; 59 : 67-72. 
2. Elliott SP, McAninch JW. Ureteral injuries: external and iatrogenic. Urol Clin North Am. 2006; 33: 55-66.

3. Goyal NK, Dwivedi US, Vyas N, Rao MP, Trivedi S, Singh PB. A decade's experience with vesicovaginal fistula in India. Int Urogynecol J Pelvic Floor Dysfunct. 2007; 18: 39-42.

4. Rao MP, Dwivedi US, Datta B, Vyas N, Nandy PR, Trivedi S et al. Postcesarean vesico-uterine fistula - Youssef's syndrome: our experience and review of published work. ANZJ Surg. 2006; 76: 243-5.

5. Haferkamp A, Wagener N, Buse S, Reitz A, Pfitzenmaier J, Hallscheidt P et al. Vesicovaginal fistulas. Urologe A. 2005; 44: 270-6.

6. Eilber KS, Kavaler E, Rodriguez LV, Rosenblum N, Raz S. Ten-year experience with transvaginal vesicovaginal fistula repair using tissue interposition. J Urol. 2003; 169: 1033-6.

7. Lee RA, Symmonds RE, Williams TJ. Current status of genitourinary fistula. Obstet Gynecol 1988; 72: 313-9.

8. Puri M, Goyal U, Jain S, Pasrija S. A rare case of vesicovaginal fistula following illegal abortion. Indian J Med Sci. 2005; 59: 30-1.

9. Härkki-Sirén $\mathrm{P}, \mathrm{Sjöberg} \mathrm{J}$, Tiitinen A. Urinary tract injuries after hysterectomy. Obstet Gynecol. 1998; 92: 113-8.

10. Tancer ML. The post-total hysterectomy (vault) vesicovaginal fistula. J Urol. 1980; 123: 839-40.

11. Gürdal M, Ayyildiz A, Huri E, Germiyanolu C. Repair of vesico-uterine fistula with the O'Conor technique. Acta Obstet Gynecol Scand. 2005; 84: 1211.

12. Kapoor R, Ansari MS, Singh P, Gupta P, Khurana N, Mandhani A, et. al. Management of vesicovaginal fistula: An experience of 52 cases with a rationalized algorithm for choosing the transvaginal or transabdominal approach. Indian J Urol. 2007; 23: 372-6.

13. El-Lamie IK. Urogenital fistulae: changing trends and personal experience of 46 cases. Int Urogynecol J Pelvic Floor Dysfunct. 2008; 19: 267-72.

14. Given FT, Acosta AA. The Martius procedure- bulbocavernosus fat flap: a review. Obstet Gynecol Surv. 1990; 45: 34-40.

15. Tancer ML. Observations on prevention and management of vesicovaginal fistula after total hysterectomy. Surg Gynecol Obstet. 1992 ; 175: 501-6.
16. Goodwin WE, Scardino PT. Vesicovaginal and ureterovaginal fistulas: a summary of 25 years of experience. J Urol. 1980; 123: 370-4.

17. Williams G. The Addis Ababa fistula hospital: an holistic approach to the management of patients with vesicovaginal fistulae. Surgeon. 2007; 5: 54-7.

18. Woo HH, Rosario DJ, Chapple SR The treatment of vesicovaginal fistulae. Eur Urol 1996; 29: 1-9.

19. Chapple C, Turner-Warwick R. Vesico-vaginal fistula. BJ U Int. 2005; 95: 193-214.

20. Blaivas J G, Heritz DM, Romanzi LI. Early versus late repair of vesicovaginal fistulas: vaginal and abdominal approaches. J Urol. 1995; 153: 1110-2; discussion 1112-3.

21. Davits RJ , Miranda SI. Conservative treatment of vesicovajinal fistulas by bladder drainaje alone.BrJ Urol. 1991; 68: 155-6.

22. Punekar SV, Buch DN, Soni AB, Swami G, Rao SR, Kinne JS et al. Martius' labial fat pad interposition and its modification in complex lower urinary fistulae. J Postgrad Med. 1999; 45: 69-73.

23. Horch RE, Gitsch G, Schultze-Seemann W. Bilateral pedicled myocutaneous vertical rectus abdominus muscle flaps to close vesicovaginal and pouch-vaginal fistulas with simultaneous vaginal and perineal reconstruction in irradiated pelvic wounds. Urology. 2002; 60: 502-7.

24. Erdemoglu E, Ozman E. Complicated vesico-urethravaginal fistula. J Turkish German Gynecol Assoc. 2008; 9: 240-2.

25. Davis RS, Linke CA, Kraemer GK. Use of labial tissue in repair of urethrovaginal fistula and injury. Arch Surg. 1980; 115: 628-30.

26. Leach GE. Urethrovaginal fistula repair with Martius labial fat pad graft. Urol Clin North Am. 1991; 18: 409-13.

27. Mondet F, Chartier-Kastler EJ, Conort P, Bitker MO, Chatelain C, Richard F. Anatomic and functional results of transperitoneal- transvesical vesicovaginal fistula repair. Urology. 2001; 58: 882-6.

28. Raut V, Bhattacharya M. Vesical fistulae - an experience from a developing country. J Postgrad Med. 1993; 39: 20-1.

29. Sharifi-Aghdas F, Ghaderian N, Payvand A. Free bladder mucosal autograft in the treatment of complicated vesicovaginal fistula. BJ U Int. 2002; 89 Suppl 1: 54-6. 